\title{
Isto não é uma pichação: afrontas (icono)gráficas e ilusões nominalistas em Joinville, SC
}

This is not a pichação: (icono)graphic affronts and nominalist illusions in Joinville, SC

Esto no es una pintada: afrentas (icono)gráficas e ilusiones nominalistas en Joinville, SC

Diego FinderMachado*

\section{Resumo}

Com base em narrativas de acontecimentos recentes em Joinville, Santa Catarina, este artigo discute a diferenciação entre as práticas da pichação e do grafite, (icono)grafias que se sobrepõem a paredes e muros da cidade. Argumenta-se que a demarcação da linha que diferencia tais práticas depende de disputas por um poder de nomeação. Em um primeiro momento, são analisados projetos de lei que visaram a criar mecanismos para coibir ações de pichadores e permitir que grafiteiros pudessem expressar sua "arte", desde que autorizados. Em seguida, a análise se volta para argumentos de estudos que explicaram as diferenças entre pichação e grafite. São perceptíveis esforços para elencar critérios objetivos de diferenciação, apostando em uma neutralidade axiológica. $\mathrm{Na}$ parte final do artigo, propõe-se suspender essa pretensa neutralidade, para compreender as palavras pichação e grafite como rótulos que atribuem valores a práticas sociais, os quais se adequariam, mais ou menos, aos ideais de "pureza", "significação" e "beleza".

Palavras-chave: Grafite. Pichação. Rotulação social.

\section{Introducão}

Para dar início ao artigo, narro três acontecimentos recentes em Joinville, cidade localizada em Santa Catarina. O primeiro deles se deu em meados de 2010, quando uma senhora idosa procurou o setor responsável pelas políticas municipais de gestão do patrimônio cultural naquela cidade. ${ }^{1}$ Ela buscava informações sobre como proceder para retirar a casa onde residia de um cadastro que elencou imóveis que possuíam, conforme análise técnica prévia, interesse patrimonial. Portanto, a casa poderia vir a ser preservada por tombamento em âmbito municipal ou, ainda, por algum outro mecanismo de proteção. ${ }^{2} \mathrm{~A}$ inclusão da casa no referido cadastro se deu por sua localização, já que remetia ao contexto urbano do período entre meados do século XIX e início do $\mathrm{XX}$, quando existiu, nas proximidades, um porto às margens do Rio Cachoeira, que corta a região central da cidade.

Doutor em História, na área de concentração História do Tempo Presente, pelo Programa de Pós-Graduação em História da Universidade do Estado de Santa Catarina. E-mail: diego_finder@yahoo.com.br

Recebido em 24.08.2018 - Aprovado em 21.09.2018 http://dx.doi.org/10.5335/hdtv.19n.1.8562 
Como depois manifestou em carta remetida ao órgão municipal de cultura, a senhora pretendia vender a casa. Na visão dela, um possível tombamento colocaria empecilhos a essa pretensão, pois o eventual comprador seria impedido de demolir o imóvel e construir no lugar o que bem entendesse. Na carta, ela tentou sensibilizar os técnicos do patrimônio para uma situação de perigo na região onde vivia, alegando que, por esse motivo, via sua segurança pessoal em risco. Como escreveu, "sou viúva e moro sozinha em uma região de alta periculosidade, sendo que já tive minha casa assaltada diversas vezes"; ainda segundo ela, a "região, como todo mundo sabe, é paradeiro de usuários e traficantes de drogas, principalmente crack" (FUNDAÇÃO CULTURAL DE JOINVILLE, 2010, p. 18). Fotografias foram anexadas ao pedido, entre as quais, algumas que destacaram pichações na fachada da casa (Figura 1 ). Nas entrelinhas, as fotografias buscavam corroborar o argumento de que havia um perigo. Entretanto, caberia indagar: por que pichações foram mostradas para fazer crer na insegurança do local? Se há evidências de insegurança, é possível afirmar que as marcas na parede foram deixadas pelas mesmas pessoas envolvidas em assaltos, furtos e tráfico de drogas?

Figura 1 - Detalhe de pichações na fachada da casa $n^{\circ} 63$ da Rua Santos, em Joinville



Fonte: Fundação Cultural de Joinville (2010, p. 21).
O segundo acontecimento se deu em 2013. Naquele ano, uma frase inusitada foi escrita no muro em frente à Catedral Diocesana São Francisco Xavier: "Tire seus rosários dos nossos ovários!" (Figura 2). A autoria do escrito foi assumida pelo coletivo feminista Mulher na Madrugada, grupo que declaradamente expressou sua crítica ao modo como a igreja católica tem condenado o aborto e se colocado como entrave nas tentativas de legalização da prática no Brasil. Esse coletivo tem se engajado em causas sensíveis que reivindicam direitos de grupos oprimidos, especialmente em lutas pelos direitos das mulheres. Entre outras táticas de ação, o coletivo costuma inscrever em paredes e muros frases contra o machismo e contra os conservadorismos cultural e religioso, buscando defender o direito de toda e qualquer pessoa de expressar sua liberdade de gênero, sexualidade e desejo.

Figura 2 - Frase pichada pelo coletivo Mulher na Madrugada, na fachada da Catedral Diocesana São Francisco Xavier de Joinville

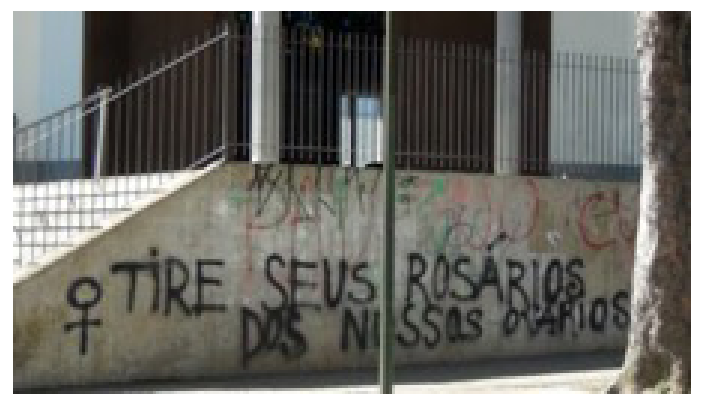

Fonte: blogue Sujeitos (TIRE..., 2013).

Sem dúvida, a frase chamou a atenção, sobretudo por ousar profanar um lugar de culto religioso. O pároco da catedral, conforme citado no blogue Sujeitos, posicionou-se sobre o ocorrido: "Como padre, não 
posso impedir que pessoas expressem suas opiniões e realizem manifestos. Porém, sou contrário a qualquer tipo de vandalismo. Esta frase, colocada em nossa parede, desqualifica o manifesto" (TIRE..., 2013, não paginado). Conforme o blogue, em 27 de junho daquele ano, "no momento em que o Papa Francisco veio para a Jornada Mundial da Juventude (JMJ), a mesma mensagem foi utilizada em cartazes e faixas por cerca de 4 mil mulheres que se manifestaram na Praia de Copacabana, no Rio de Janeiro" (TIRE..., 2013, não paginado). Em sua manifestação, o pároco desqualificou o ato de pichação como "vandalismo", insinuando, com o rótulo, que se tratou de ação bruta e impensada, o que colocava em descrédito as possíveis boas intenções da manifestação. Assim, a pichação foi vista como afronta à ordem que regula a convivência na cidade. Porém, seria necessário perguntar: É possível se manifestar contra opressões na cidade sem, antes, ousar romper com a própria ordem social que permite tais formas de opressão e dá ensejo a elas?

O terceiro acontecimento, muito emblemático, foi noticiado em 2014. No dia 29 de junho, a Prefeitura de Joinville divulgou nota, em sua página na rede social Facebook, informando que o monumento A Barca havia sido alvo de pichações. Os autores, não identificados, deixaram tags sobre a face do monumento, assinaturas estilizadas que demarcam um modo peculiar de inscrever-se no espaço urbano (Figura 3). Foi um acontecimento com forte potência simbólica, visível em um lugar de poder: defronte da Prefeitura de Joinville. As assinaturas restaram como rastros da audácia de sujeitos que descumpriram proibições e burlaram a vigilância. Na nota, a Prefeitura de Joinville lamentou o ato: "Atitudes como essa denigrem não só a imagem da cidade como a história de Joinville" (PREFEITURA DE JOINVILLE, 2014, não paginado).

Figura 3 - Pichações no monumento A Barca

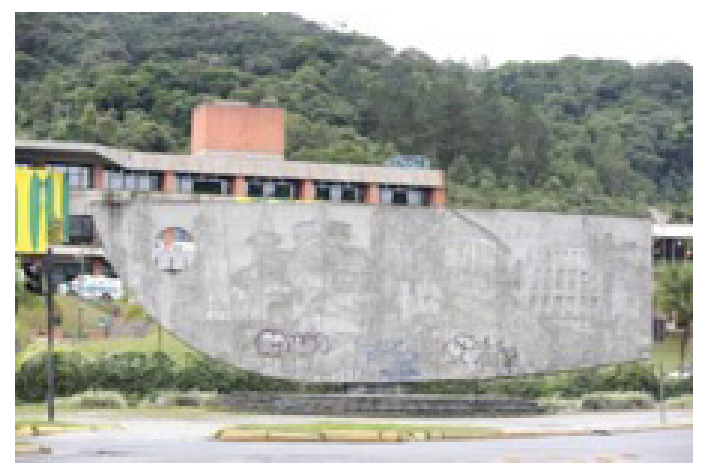

Fonte: Prefeitura de Joinville (2014).

$\mathrm{O}$ ato foi particularmente provocativo, porque, no ano anterior, o prefeito Udo Döhler tinha tomado a ação de limpeza do monumento como evento simbólico daquilo que ele almejava para toda a cidade. Logo no início de sua gestão à frente da Prefeitura de Joinville, o prefeito deu ordens para que fosse iniciado um movimento de "depuração" de espaços públicos. As ações envolveram pintura de fachadas e corte de árvores, assim como limpeza e reparo de edificações. Tal movimento de depuração foi iniciado com o ato ritualístico de lavação do monumento A Barca. O monumento, projetado pelo designer César Dobner, foi inaugurado em 09 de março de 2001, para comemorar os 150 anos da cidade. Na época, as comemorações foram organizadas pelo Instituto Joinville 150 Anos, entidade presidida justamente por Udo Döhler, empresário local que era cônsul 
honorário da Alemanha. Em janeiro de 2013, imagens divulgadas na página da Prefeitura de Joinville na internet mostraram um trabalhador içado por um guindaste a proceder a limpeza do monumento com uma lavadora de alta pressão. Tratou-se, portanto, de um movimento com vistas a afastar males que poderiam ser causados se o espaço urbano permanecesse com aspecto sujo e malcuidado, isto é, com a impressão de "desordem".

O acontecimento, contudo, não foi tomado apenas como afronta à imagem de uma cidade que corresponderia aos anseios de limpeza e segurança, mas, sobretudo, como afronta à história de Joinville. Protegidos pelo anonimato, pichadores ousaram macular a história metonimicamente inscrita na face do monumento, ataque àquilo que se acreditou ser a representação autêntica da "identidade" da cidade. Elementos estranhos e perturbadores foram sobrepostos à narrativa visual que demarcou no espaço e perenizou no tempo símbolos eleitos como "típicos" de Joinville: carroças, bicicletas, orquídeas, chaminés, casas enxaiméis, palmeiras, bailarinos, entre outros. Se a pichação, por um lado, subverteu a "pureza" de uma ordem social, por outro, subverteu a "pureza" de uma "ordem patrimonial", ao macular a presumida "autenticidade" do passado. Nesse ponto, outras questões se colocariam: pichações no espaço urbano, tais quais as tags sobre o monumento, sinalizam os limites das tentativas de fazer com que os cidadãos se identifiquem com a cidade e seu patrimônio? Ou pode-se presumir que sujeitos, ao deixarem assinaturas, exprimiram uma forma de identificação, ainda que des- toante em relação à "identidade" imaginada na cidade?

As questões indicadas evocam ligações possíveis entre o que se entende por "patrimônio" e por "identidade". Para Paulo Peixoto (2004), não há simplicidade em uma equação que envolva esses termos, os quais, em linguagem matemática, ele considerou incógnitas. Como explicou, caso se opte pela simplicidade da equação, o que tem sido recorrente, corre-se o risco de adotar "uma concepção excessivamente essencialista de identidade"; há, também, o risco de sermos "confrontados com uma concepção de património que não deixa transparecer devidamente o seu caráter de ficção cultural ao mesmo tempo encantatória, selectiva e idealizadora" (PEIXOTO, 2004, 184). É preciso perceber, por um lado, que valores patrimoniais são invenções atribuídas a bens culturais em dado momento e não qualidades intrínsecas a tais bens. Os atos de patrimonialização, nesse sentido, estão sempre sujeitos a dissensos e se afirmam em um campo de conflitos e disputas. Por outro lado, é forçoso admitir uma concepção não essencialista de identidade, levando em consideração que as maneiras como nos identificamos com pessoas e coisas (ou, ainda, como delas nos diferenciamos) se produzem socialmente por relações assimétricas e difusas de poder. Afinal, as identificações nem sempre se expressam da maneira como a maior parte das pessoas desejaria.

O que conecta os três casos narrados, acontecimentos muito diferentes e com objetivos bastante incongruentes, é apenas um rótulo: a palavra "pichação" aplicada para nomear práticas (icono)gráficas de subver- 
são da ordem na cidade. No primeiro caso, pichação é sinal de perigo iminente. No segundo, profanação do sagrado. Já no terceiro, afronta ao valor simbólico da história da cidade. Portanto, o rótulo "pichação" se mostra uma amarra frouxa para atar no mesmo discurso condenatório diferentes formas de desviar-se de normas estabelecidas e de subverter uma ordem desejada no convívio em sociedade. Não é à toa que a palavra pichação comumente é vinculada a outros rótulos depreciativos, como, por exemplo, à palavra "vandalismo", no sentido de ato bárbaro, ou seja, bruto e inconsequente. ${ }^{3}$ Para certos indivíduos e grupos que sobrepõem (icono)grafias sobre muros e paredes das cidades, a palavra pichação é demasiado genérica. Preferem identificar-se como pixadores e classificar os próprios trabalhos como pixações, substituindo as letras "ch" pela letra " $x$ ", um neografismo que busca marcar distintividades ética e estética. ${ }^{4}$

Os discursos que rejeitam o valor de sobreposições (icono)gráficas em muros e paredes das cidades costumam instituir uma linha de diferenciação um tanto rígida entre a pichação, considerada sujeira que afronta a ordem e agride o olhar, e o grafite, considerado manifestação artística que compõe a paisagem visual. Há, portanto, a configuração de uma "política nominalista da diferença". A linha que diferencia o que se denomina "pichação" daquilo que se denomina "grafite" depende de disputas pelo poder que se manifestam em atos de linguagem. Tais atos fixam marcadores de diferenças sustentados em estereótipos e estigmas, com vistas a fazer valer uma ideia de "ordem" e segregar tudo e todos que pareçam estar "fora do lugar".
Segundo Stuart Hall (2016), ainda que tipificar seja ato essencial à produção de sentidos na vida social, há o risco de se incorrer em "estereotipagens". Isso ocorre quando as tipificações se reduzem a características essencializadas, que "fixam" a diferença. Para ele, "a estereotipagem implanta uma estratégia de 'cisão', que divide o normal e aceitável do anormal e inaceitável" (HALL, 2016, p. 191, grifo do autor). Os estereótipos, portanto, tomam as diferenças culturais como desigualdades supostamente "naturais". O estigma, por sua vez, desloca ao "outro" a origem de sua presumida inferioridade, identificável em sinais diacríticos que expõem a diferença que o segrega da vida "normal". Como explicou Erving Goffman (2012), na vida social, há discrepância entre a "identidade social virtual", moldada pela exigência de "normalidade", e a "identidade social real", os atributos que, de fato, provamos possuir. Um estigma é a marca visível dessa discrepância, que vem à tona nas situações em que "um indivíduo que poderia ter sido facilmente recebido na relação social quotidiana possui um traço que pode-se [sic] impor à atenção e afastar aqueles que ele encontra" (GOFFMAN, 2012, p. 14). Alguns rótulos sociais, a exemplo da palavra "pichador", atuam como estigmas que marcam uma "anormalidade" que teria origem em supostos "comportamentos desviantes", e não em estereótipos que tomam por desviantes comportamentos alheios. Portanto, a ideia de "desvio" deve ser entendida como uma criação contingente e contextual. Para Howard Becker, “o desviante é alguém a quem esse rótulo foi aplicado com sucesso; o comportamento desviante é aquele que as 
pessoas rotulam como tal" (2008, p. 22). Desloca-se, assim, de uma abordagem "comportamental" para uma abordagem "definicional".

O título deste artigo faz alusão à frase Ceci n'est pas une pipe (Isto não é um cachimbo) grafada na obra A traição das imagens, de René Magritte, e é inspirado na análise da obra proposta por Michel Foucault (2016). Segundo o filósofo, naquela obra em particular, "Magritte liga os signos verbais e os elementos plásticos, mas sem se outorgar, previamente, uma isotopia; esquiva o fundo do discurso afirmativo, sobre o qual repousava a semelhança" (FOUCAULT, 2016, p. 70). A questão a que ele quis atentar se refere ao fato de que nem sempre há equivalência, tampouco semelhança, entre aquilo que se pode ver e aquilo que se pode dizer, isto é, entre visibilidades e enunciados. Essa foi a ironia de Magritte, ao dizer-nos que, ainda que vejamos um cachimbo na pintura, não se trata, por certo, de um cachimbo, mas apenas de sua representação pictórica. Ao parodiar a frase de Magritte, busco alertar para o fato de que, entre as imagens, tais quais as sobreposições (icono)gráficas discutidas neste estudo, e as nomeações que lhes são atribuídas, interpõem-se disjunções. Nunca é tarefa óbvia e fácil dar nome a coisas e práticas sociais, pois há sempre disputas pelo poder de nomeação. Isso ocorre, sem dúvida alguma, nas contendas para demarcar a linha de diferenciação entre práticas denominadas de "pichação" e de "grafite". Ainda que a certos agentes sociais seja possível identificar objetividade no traçado dessa linha, é preciso ter em mente que chamar algo de "pichação" ou de "grafite" é ato subjetivo que atribui valor, o que, por vezes, implica apreciar determinados atos e atores, ao passo que deprecia outros.

Ao problematizar processos de demarcação da linha de diferenciação entre pichação e grafite, analiso neste artigo, em um primeiro momento, projetos de lei que visaram a criar mecanismos para coibir ações de pichadores e a permitir que grafiteiros possam expressar sua "arte", desde que devidamente autorizados. Em seguida, analiso argumentos de estudos que explicaram as diferenças entre pichação e grafite. São perceptíveis esforços para elencar critérios objetivos de diferenciação, apostando, desse modo, em uma neutralidade axiológica. Na parte final do artigo, proponho colocar em suspensão essa pretensa neutralidade, para compreender as palavras "pichação" e "grafite" como rótulos que atribuem valores a práticas, valores que se adequariam, mais ou menos, a ideais de "pureza", "significação" e "beleza".

\section{(Icono)grafias urbanas: definir limites ou transpor limiares?}

Em 2014, após o caso das sobreposições de tags sobre a face do monumento A Barca, surgiram em Joinville os primeiros debates no legislativo municipal a respeito, com o objetivo de propor leis para coibir e punir a prática da pichação na cidade. De Maycon Cesar, vereador na época pelo Partido Popular Socialista, o Projeto de Lei Ordinária n ${ }^{\circ}$ 381/2014 buscava "a prevenção e a punição de atos de pichação, vandalismo e depredação do patrimônio público". Conforme a proposta, seria instituída a "Políti- 
ca Municipal Contra Pichações", visando a "construir um ambiente urbano com qualidade visual satisfatória" e a "conscientizar e esclarecer a população sobre os prejuízos que a prática da pichação acarreta à sociedade" (CÂMARA DOS VEREADORES DE JOINVILLE, 2014b, não paginado). Para tanto, seriam tomadas medidas de educação e fiscalização, além de controle na venda de tintas sprays e similares. Em 2016, o projeto, sequer discutido nas comissões legislativas, foi arquivado ao fim do mandato legislativo (CÂMARA DOS VEREADORES DE JOINVILLE, 2014b). Já outra proposta, também de 2014, foi desarquivada em 2017 e segue em discussão. O Projeto de Lei Complementar $n^{\circ}$ 24/2014 (CÂMARA DOS VEREADORES DE JOINVILLE, 2014a), de Fábio Dalonso, vereador pelo Partido Social Democrático, reitera as disposições da Lei Federal ${ }^{\circ}$ 12.408 , de 25 de maio de 2011, no que se refere à proibição da comercialização de tintas em embalagens de tipo aerossol a menores de dezoito anos. Contudo, propõe o adendo de que caberá aos estabelecimentos que vendem tais produtos a obrigatoriedade de manter cadastro dos compradores.

Para entender as iniciativas do legislativo de Joinville, vale retomar o percurso da aprovação da Lei Federal no ${ }^{\circ}$ 12.408, de 25 de maio de 2011. Esta lei, ao alterar o Art. 65 da lei de crimes ambientais (Lei Federal $\mathrm{n}^{\circ}$ 9.605, de 12 de fevereiro de 1998), acabou por descriminalizar a prática do grafite no país. Embora possa ser vista como norma que valorizou o grafite, reconhecido como expressão artística, a ideia inicial do projeto se limitava a buscar meios para acirrar o combate da pichação e controlar a venda de tintas em embalagens aerossóis. De Geraldo Magela, deputado do Distrito Federal pelo Partido dos Trabalhadores, o Projeto de Lei n ${ }^{\circ}$ 706/2007 (CÂMARA DOS DEPUTADOS, 2007), de 10 de abril de 2007, propôs atribuir dois parágrafos ao Art. 65 da lei de crimes ambientais, distinguindo os termos "pichação" e "grafite". A pichação foi categorizada como "ação ilegal e criminosa que degrada o patrimônio público e privado, além de inferir de forma negativa na paisagem e meio ambiente urbano". Ao grafite, por sua vez, foi atribuída denotação positiva, como "prática que tem como objetivo a valorização do patrimônio público e privado mediante manifestações artísticas sob o consentimento de seus proprietários" (CÂMARA DOS DEPUTADOS, 2007, não paginado).

O relator do projeto na Comissão de Meio Ambiente e Desenvolvimento Sustentável, o deputado Germano Bonow, propôs ajustes ao texto inicial. Manifestou, contudo, opinião de que a proposta era oportuna, já que "as lamentáveis pichações que todos os dias vemos nos muros e prédios são um desrespeito à paisagem urbana, à propriedade e à Lei". Alertou, ainda, que "no mais das vezes, são ações promovidas por adolescentes, muitos dos quais lamentavelmente envolvidos com gangues, se não violentas, no mínimo delinquentes" (CÂMARA DOS DEPUTADOS, 2007, não paginado). Já para o deputado Miguel Corrêa Jr., relator na Comissão de Desenvolvimento Econômico, Indústria e Comércio, a pichação é ato de "vandalismo": "Lamentavelmente, monumentos e edificações são alvos de vandalismo em quase todas as cidades brasileiras". Também vinculou o ato de pichar a crimes, 
pois, para ele, "além da deterioração de bens públicos e privados, essas ações estão frequentemente associadas a outros problemas, como a violência e o uso de drogas" (CÂMARA DOS DEPUTADOS, 2007, não paginado). Ele louvou a iniciativa de diferenciar pichação e grafite, combatendo a ação ilegal e valorizando a expressão artística. Por sua vez, o deputado Nelson Pellegrino, relator na Comissão de Constituição e Justiça e de Cidadania, propôs emendas formais e concluiu pela relevância do projeto, já que a medida legislativa poderia "oferecer uma resposta mais eficaz no combate à prática da pichação já tão banalizada" (CÂMARA DOS DEPUTADOS, 2007, não paginado). Aprovado com emendas em plenário, em $20 \mathrm{de}$ agosto de 2008, o projeto seguiu para discussão no Senado Federal.

Ao tramitar no Senado Federal, como Projeto de Lei da Câmara no 138 (SENADO FEDERAL, 2007), o texto foi relatado na Comissão de Constituição, Justiça e Cidadania pela senadora Marina Silva. Ela se posicionou em defesa de um "meio ambiente limpo opticamente", já que, na opinião dela, a pichação não se restringe a "mero ato de dano", mas "como expressão de desrespeito ao direito difuso de se ter um ambiente visualmente limpo". Entretanto, alertou para a necessidade de ir além das medidas repressivas, tendo em vista que a pichação deveria ser "tratada a partir de uma visão socioeducativa, capaz de acolher a necessidade que tem estes jovens de algum espaço para dar curso às suas necessidades de expressão". A senadora apoiou a proposta de descriminalizar a prática do grafite que, nas palavras dela, "seria uma forma de expres- são artístico-visual (plástica ou não) que utiliza um conjunto de palavras e/ou imagens a fim de dar forma a uma ideia". Quanto à pichação, disse que seria "complexo admitir o argumento de que a conduta reflete o direito à liberdade de expressão de um indivíduo", pois, para ela, "a poluição visual decorrente das diversas inscrições, símbolos e desenhos, na grande maioria das vezes, sequer é decifrada pela população, que não vislumbra qualquer fundamento ou motivo" (SENADO FEDERAL, 2007, não paginado). Na Comissão de Meio Ambiente, o senador Cícero Lucena sugeriu duas emendas ao projeto, uma propondo alteração da ementa, para deixar claro que se buscava descriminalizar o grafite, e outra propondo aperfeiçoar a redação do $\$ 2^{\circ}$ que seria acrescido ao Art. 65 da Lei no 9.605/1998, de modo a não recair em definições taxativas: "Não constitui crime a prática de grafite realizada com o objetivo de valorizar o patrimônio público ou privado mediante manifestação artística, desde que consentida pelo proprietário" (SENADO FEDERAL, 2007, não paginado).

Ao retornar à Câmara dos Deputados, em 22 de dezembro de 2009, o projeto com as emendas propostas seguiu para nova análise. O deputado Leonardo Monteiro, na Comissão de Meio Ambiente e Desenvolvimento Sustentável, opinou que o projeto ficou "mais direto no que pretende tipificar como crime ao patrimônio ambiental", pois "evitou estabelecer conceitos sobre grafitagem ou pichação", que são "controversos no próprio meio social em que são aplicados" (CÂMARA DOS DEPUTADOS, 2007, não paginado). Em 28 de abril de 2011, as emendas foram aprovadas e, em 25 de maio, a Lei 
Federal $\mathrm{n}^{\circ} 12.408$ foi sancionada pela presidenta Dilma Rousseff.

O mesmo cuidado em evitar definições irredutíveis não foi levado em conta em três projetos apresentados em 2017 na Câmara dos Vereadores de Joinville. Do vereador Lioilson Corrêa, do Partido Social Cristão, o Projeto de Lei Ordinária no 356/2017 (CÂMARA DOS VEREADORES DE JOINVILLE, 2017c) teve o intuito de autorizar o executivo municipal a restaurar a pintura de lugares públicos ou privados pichados. Conforme o projeto, pichação é "palavra, dizer, imagem, frase e/ou letras desconexas, sem qualquer dimensão estética, escritas, pintadas ou desenhadas nos muros e fachadas de imóveis públicos e particulares". Esse tipo de intervenção, para o vereador, causa "aspectos negativos na paisagem e no ambiente urbano". O grafite, em vez disso, compreende "palavras, frases ou desenhos de cunho artístico, escritas, pintadas ou desenhadas com a devida autorização do proprietário ou do órgão público competente". Neste caso, o objetivo é "valorizar a paisagem e o ambiente urbano". Ainda conforme o projeto, caberia a adolescentes encaminhados judicialmente para prestar serviços comunitários a responsabilidade pela "restauração", como medida socioeducativa. O projeto propôs, também, multa a quem for flagrado cometendo a pichação. Como justificado, alegou-se ser importante preservar "a integridade dos traços que definem um bem cultural, pois eles constituem a nossa identidade" (CÂMARA DOS VEREADORES DE JOINVILLE, 2017c, não paginado).

Dois outros projetos de lei buscaram criar mecanismo de vigilância e controle. $\mathrm{O}$
Projeto de Lei Ordinária nº 141/2017 (CÂMARA DOS VEREADORES DE JOINVILLE, 2017b), do vereador Adilson Girardi, do Solidariedade, quis instaurar na cidade o mecanismo de denúncia nominado Patrulha Antipichação. Segundo o projeto, caberia ao poder executivo municipal, por meio da Secretaria de Proteção Civil e Segurança Pública, disponibilizar um número de telefonia móvel para receber, via aplicativo WhatsApp, denúncias. Como justificado, a pichação acaba por "desqualificar o patrimônio alheio de forma delinquente e sem reflexão sobre os conteúdos". Para o vereador, "o crime de pichação é prática extremamente prejudicial à imagem estética e visual dos ambientes urbanos, causando um estado de sujeira e confusão". Tendo em vista tratar-se, na opinião dele, de "problema social relevante", a norma legal poderia "promover o envolvimento da população na zeladoria e cuidado da cidade" (CÂMARA DOS VEREADORES DE JOINVILLE, 2017b, não paginado). Essa proposta foi rejeitada na casa legislativa.

Por sua vez, o Projeto de Lei Complementar n ${ }^{\circ}$ 54/ 2017 (CÂMARA DOS VEREADORES DE JOINVILLE, 2017a), de Fábio Dalonso, propôs alterar o Código de Posturas do Município, para criar o Programa de Combate à Pichação e o mecanismo designado Disque-Pichação. Ao vereador, o programa visaria a "confrontar a poluição visual e a degradação paisagística". Tal programa funcionaria junto à Secretaria do Meio Ambiente, órgão do município que receberia denúncias por contato telefônico ou eletrônico. O projeto manifestou o entendimento de que pichar é ato de "riscar, desenhar, escrever, borrar ou por outro meio conspurcar edifi- 
cações públicas ou particulares". Ficariam fora do programa "grafites realizados com o objetivo de valorizar o patrimônio público ou privado mediante manifestação artística, desde que consentida". Na justificativa, o vereador manifestou a intenção de que a lei pudesse "diminuir e até extinguir a prática de pichar, que suja e polui visualmente propriedades particulares, prédios públicos, pontes, viadutos, etc. Prejudicando a imagem da nossa cidade [...]" (CÂMARA DOS VEREADORES DE JOINVILLE, 2017a, não paginado). Neste caso, o proponente acabou por retirar de pauta o projeto.

Tais debates legislativos com vistas a coibir a prática da pichação, bem como a eximir de punições a prática autorizada do grafite, são momentos de redefinição de uma política nominalista. Grafite e pichação, conforme a visão expressa nos projetos de leis, são nomes utilizados para separar mundos avessos. Para os legisladores, grafiteiros e pichadores, no que tange a atitudes e comportamentos na vida urbana, seriam antagonistas uns dos outros, como se fossem encarnações do bem e do mal a que a cidade está sujeita. Os projetos buscaram definir limites objetivos àquilo que, na cidade, poderia ser considerado "puro", "significativo" e "belo" e que, por isso, seria "permitido". Seus autores almejaram se valer da força da lei para banir práticas que deixam na cidade marcas visuais de aspecto "sujo", "indecifrável" e "feio", práticas que descambam às margens do "proibido". De lugares institucionais de poder, investiram-se esforços, para normatizar condutas e "normalizar" sujeitos, buscando dar objetividade a uma linha de diferenciação delineada por razões e sensibilidades subjetivas.
Os desdobramentos da eventual aprovação de algum dos projetos de lei antipichação em Joinville foram debatidos em reportagem publicada no site Paralelo Jornalismo. A questão controversa, conforme as pessoas ouvidas, é a dificuldade para precisar limites inequívocos entre as intervenções rotuladas de pichação ou de grafite. Para o vereador Adilson Girardi, citado na reportagem, deveria haver investimentos em ações educativas para esclarecer a população sobre o que é e o que não é arte, ou seja, sobre que é e o que não é grafite: “Uma das ideias seria chamar as pessoas que trabalham com arte para levar às escolas e redes sociais a informação a respeito do que é para saberem diferenciar". Daí decorreria uma solução ao problema: quando pichadores, devidamente instruídos, "mudem o foco" e "façam arte". Já ao crítico de arte Gleber Pieniz, a questão não é tão simples, pois as diferenças entre tais práticas estão sujeitas a avaliações subjetivas, e "essa subjetividade acaba sendo, pelo o que está subentendido na lei, uma avaliação por parte de quem faz a denúncia e pelo órgão público que vai cobrar ou fiscalizar". Como ele explicou, não há consenso sobre a diferença, nem mesmo entre praticantes, pois "eles se aproximam muito e algumas vezes o grafiteiro também faz o pixo ou o pichador acaba se tornando um grafiteiro com o decorrer do tempo". Na opinião dele, "muitas vezes, pichação e grafite num mesmo trabalho colocado na rua têm fronteiras muito tênues". Semelhante posição foi assumida por Gôri, grafiteiro de 23 anos de idade, para quem "o pixo pode ser grafite também, não tem como definir só porque eu estou usando mil cores ou uma cor só". Se- 
gundo ele, "tem como diferenciar pichação e grafite como movimentos culturais, mas a forma como acontece na cidade, que é escrever ilegalmente na parede, é a mesma". Além disso, alertou para o risco de uma diferenciação restrita à avaliação estética:

Então imagina uma pessoa sem informação do que é e o que não é grafite ou pichação, ele vai dizer "isso aqui eu acho feio, vou apagar, isso é bonito, então vou deixar". Mas bonito pra quem, né? (GUERREIRO, 2017, não paginado).

A dificuldade de diferenciação é observada, inclusive, em livros e trabalhos acadêmicos. Para Celso Gitahy (1999), a diferença entre pichação e grafite é muito tênue, já que ambas as práticas se utilizam da cidade como suporte e se valem de tintas. A diferença se situaria, então, em aspectos formais, pois "o graffiti privilegia a imagem; a pichação, a palavra e/ou a letra" (GITAHY, 1999, p. 19). Porém, ao indicar um estilo híbrido, o "grapicho" mostrou a fragilidade dessa diferenciação. O grapicho, pichação mais colorida, indica as interações criativas entre pichadores e grafiteiros. Seguindo semelhante argumentação, Bruno Ramos Rodrigues (2016) destacou, além de aspectos formais, a diferença quanto a aspectos comunicacionais, com mensagens dirigidas a um público amplo ou apenas a um seleto grupo de intérpretes iniciados. Segundo ele, o grafite "busca comunicar-se com o outro a partir das cores de seus desenhos e letras, tendo maior preocupação com a estética e com a comunicação ampla"; já a pichação é "restrita à subversão e a uma preocupação com a construção de letras e códigos que se comunicam - de maneira monocromática
- com grupos específicos capazes de decodificar a sua escrita" (RODRIGUES, 2016, p. 103-104).

Tal modo de diferenciação, pautado nas próprias obras, tem a vantagem de deslocar a análise dos estereótipos elaborados por outros, para se aproximar das intenções de atores sociais ao praticarem pichação e grafite. Não obstante, trata-se de uma linha de diferenciação movediça. Como sustentar que a pichação se restringe a comunicar-se por palavras, quando pichadores se mostram atentos à força imagética da caligrafia, a qual, por vezes, se sobrepõe ao conteúdo textual? É preciso lembrar que a caligrafia é um tipo de iconografia, uma expressão imagética. Além disso, é crível a ideia de que o grafite se apresenta legível aos olhos de um público abrangente, enquanto a pichação é apenas marca esotérica a ser decifrada por iniciados? A leitura de textos e imagens exige conhecimento e reconhecimento de códigos culturais que estão para além do visível. Há mundos invisíveis que transpassam o que se pode ver, mundos que exigem alguma iniciação para decifrá-los.

Outro tipo de argumentação desloca o foco para as práticas e os discursos que condenam inscrições em muros e paredes, sustentando a linha de diferenciação entre pichação e grafite na dicotomia entre legalidade e ilegalidade. De acordo com Daniel Mittmann, a condenação da pichação ganha força nessa dicotomia, pois trata-se de "prática ilegal, a qual afronta o patrimônio público e privado e dessa feita deve ser negada e combatida" (2013, p. 86). Em discursos condenatórios, a diferença se mostra simples: "a pichação é caracterizada pela sua não auto- 
rização, por isso ilegalidade, já o grafite configura-se pela mesma intervenção plástica, mas seguida da autorização" (MITTMANN, 2013 , p. 87). Embora indique a arbitrariedade da diferenciação, o autor argumenta que a dicotomia entre legal e ilegal é relevante para compreender subjetividades de sujeitos que intervêm em muros e paredes das cidades. Para ele, é a "representação marginal que é explorada de forma positivada e de diferenciação de outras práticas pelos pichadores" (MITTMANN, 2013, p. 87).

Esse argumento tem a vantagem de dar a perceber o caráter intersubjetivo de processos de elaboração de subjetividades. Pichadores e grafiteiros se constroem enquanto sujeitos não apenas pelas próprias ações e vontades, mas também em face do modo como são interpelados por práticas e discursos que buscam normatizar suas condutas e normalizar suas identidades. Porém, também nessa perspectiva um problema se coloca: como delinear com clareza a linha que separa o legal do ilegal? Se a ideia de "legalidade" estiver restrita ao teor de uma norma jurídica, é possível objetivar a linha de diferenciação: perante a lei, a pichação é ilegal, e o grafite é legal. Porém essa linha não se sustenta apenas na eficácia jurídica de uma norma, mas, sobretudo, em sua eficácia social. Nem todas as leis instituídas, embora válidas e vigentes, mantêm-se eficazes na vida social, muitas acabam se tornando "letra morta". Mais do que mera formalidade jurídica, a dicotomia legal/ilegal depende de investimentos sociais, para que determinadas normas tenham, de fato, efeitos práticos. É preciso se perguntar: quem possui o poder de definir e redefinir o que é legal ou ilegal e, assim, impor regras aos outros? Os pichadores, ainda que cientes de que seus atos são considerados reprováveis, estão dispostos a concordar com as práticas e os discursos que tomam o que fazem como atos ilegais? Penso que é necessário reconhecer nuances entre o que pode ser considerado legal ou ilegal, ou, ainda, justo ou injusto.

Ambos os argumentos, ora apoiados nas obras e em suas características formais e comunicacionais, ora nas fronteiras da legalidade, deixam espaço a tantas exceções que acabam por se mostrar insustentáveis. Do ponto de vista daquilo que sujeitos fazem ao sobrepor grafias e iconografias sobre muros e paredes das cidades, eu tenderia a sugerir a abolição da linha de diferenciação entre pichação e grafite, que, por sinal, apenas se sustenta taxativamente no Brasil. Entretanto, seria insensato desconsiderar a força dessas palavras para rotular comportamentos e atitudes.

\section{Uma ilusão nominalista}

Ao posicionar-me no debate, proponho tomar as palavras pichação e grafite como rótulos utilizados para (des)valorizar práticas sociais. Os autores citados, cada qual ao seu modo, buscaram uma neutralidade axiológica, para demarcar a linha de diferenciação, pautando critérios objetivos. A meu ver, faz-se necessário suspender essa pretensa neutralidade para perceber como, no Brasil, as práticas da pichação e do grafite são diferenciadas por critérios subjetivos de valoração. Tal postura analítica ajuda a compreender melhor o teor dos projetos legislativos com o objetivo de criar mecanismos 
para coibir a pichação. Na trama que envolve tais projetos, perfilam-se argumentos para justificar limites ao que pode ser visto como "ambientalmente correto", "expressivamente eficaz" e "artisticamente aceito", isto é, intervenções que corresponderiam, mais ou menos, aos valores de "pureza", "significação" e "beleza".

A defesa do "ambientalmente correto" volta-se contra um tipo particular de "poluição", que, a princípio, não afronta a higiene nem provoca doenças, mas agride o olhar, o que se convencionou chamar de "poluição visual". Ao considerar a pichação como forma de "poluição visual", os projetos legislativos buscam preservar um valor de "pureza" atribuído a coisas e a pessoas, o que implica a vontade de limpar o que se considera sujo e, no caso de bens patrimonializados, de afastar tudo o que possa descaracterizar o que se acredita autêntico.

Quanto ao anseio do "expressivamente eficaz", há a crença de que a cidade pode e deve se mostrar plenamente transparente e legível aos habitantes. Contudo, não há como ser indiferente às opacidades e aos diversos sinais difíceis de decifrar que se interpõem na construção de significados na vida urbana. Se as pichações são sinais esotéricos ao cidadão comum, o mesmo se pode dizer de outras técnicas de comunicação urbana, a exemplo da publicidade. É preciso também reconhecer que, embora algumas pichações, ao apresentar simbologia cifrada ao olhar leigo, não comuniquem algo em linguagem direta, indiretamente transmitem mensagens, seja ao menos para dizer que sujeitos invisibilizados querem se fazer notados pe- las suas assinaturas inscritas no espaço público.

O tópico mais controverso, porém, é o argumento de que permissões somente deveriam ser concedidas a intervenções "artisticamente aceitas", tomando a "beleza" como valor relevante de avaliação estética. Neste caso, os legisladores se arrogaram do direito de definir o que seria e o que não seria artístico, admitindo o poder legislativo como instância legítima para reconhecer e regular a arte. Valho-me aqui do conceito de "artificação", tal como proposto por Roberta Shapiro (2007). Para ela, "a artificação é o processo pelo qual os atores sociais passam a considerar como arte um objeto ou uma atividade que eles, anteriormente, não consideravam como tal" (SHAPIRO, 2007, p. 137). Trata-se, assim, do deslocamento da fronteira que separa o que é considerado arte daquilo que não o é. O grafite, manifestação que emergiu como transgressão exercida por jovens de periferias urbanas, foi, nas últimas décadas, "artificado", o que implicou sua aceitação em circuitos institucionais, mercadológicos e acadêmicos da arte. A pichação, ao contrário, ainda se mantém como prática transgressora e resiste a ser absorvida por uma concepção normalizadora de arte. Por isso, joga com formas de expressão estética que colocam em xeque a dicotomia entre o que é considerado belo ou feio, desestabilizando as convenções que limitam o "artificável".

Entre o visível de uma (icono)grafia sobreposta a uma parede ou um muro da cidade e o que isso pode nos dizer, há um entremeio onde se operam jogos políticos para nomear atos e atores sociais. Dizer "isto 
é uma pichação" ou "isto não é uma pichação" é rotular uma prática social, demarcando seus limites em relação a outras práticas. Por vezes, busca-se demarcar tais limites por força de lei, como tem ocorrido em Joinville. Em tais situações, há a vontade de apartar o mau da pichação, ação ilegal exercida por sujeitos considerados delinquentes, do convívio entre "pessoas de bem". A essas caberia o dever de agir na educação e na "correção" de comportamentos alheios e, ainda, de assumir a função de "zeladores" da cidade, delatando às autoridades atos que lhes pareçam afrontar a limpeza e a segurança do lugar onde vivem. Pensar que a questão se resolveria ao elencar critérios objetivos de diferenciação não passa de uma "ilusão nominalista", o que oculta acirradas disputas pelo poder de nomeação. Abandonar essa ilusão talvez nos ajude a perceber melhor tais disputas de poder e, ainda, a estar mais atentos a limiares que são transpostos por pichadores e grafiteiros em suas vivências no cotidiano da cidade.

\section{Abstract}

Based on narratives of recent events in Joinville, Santa Catarina, this article discusses the distinction between pichação and graffiti practices, (icono)graphies that overlap walls of the city. It is argued that the demarcation of the differentiation line of such practices depends of the disputes over a power of nomination. Initially, were analyzed draft bills that aimed to create mechanisms to curb pichadores actions and allow graffiti artists to express their "art", provided they are authorized. In sequence, the analysis is focused on the studies arguments that explained the differences between pichação and graffiti. Efforts are being made to list objective criteria of differentiation, betting on axiological neutrality. In the final part of the article, it is proposed to suspend this supposed neutrality to understand the words pichação and graffiti as labels that attribute values to social practices, which would more or less suit the ideals of "purity", "meaning" and "beauty".

Keywords: Graffiti. Pichação. Social labelling.

\section{Resumen}

Basado en narraciones de acontecimientos recientes realizados en Joinville, Santa Catarina, este artículo discute la diferenciación entre las prácticas de la pintada y del grafitti, iconografías que se sobreponen a las paredes y muros de la ciudad. Se argumenta que la demarcación de la línea que diferencia tales prácticas depende de disputas por un poder de nominación. En un primer momento, se analizan proyectos de ley que pretendían crear mecanismos para cohibir las acciones de quien hace pintadas y permitir que los grafiteros pudiesen expresar su "arte", desde que estuviesen previamente autorizados. Posteriormente, se profundiza en los argumentos de estudios que explican las diferencias entre pintada y grafitti. Son perceptibles esfuerzos para definir criterios objetivos de diferenciación, apostando por una neutralidad axiológica. A modo de conclusión, se propone suspender esa pretendida neutralidad para comprender 
las palabras pintada y grafitti como etiquetas que atribuyen valores a prácticas sociales, que se adecuan, más o menos, a los ideales de "pureza", "significado" y "belleza".

Palabras clave: Grafitti. Pintada. Etiquetado social.

\section{Notas}

1 Desde 1982, a Fundação Cultural de Joinville ficou responsável pela gestão das políticas municipais de patrimônio cultural. Em 2017, com uma reforma administrativa, tal fundação e suas unidades foram incorporadas à Secretaria de Cultura e Turismo.

2 Os tombamentos municipais em Joinville são regidos pela Lei $\mathrm{n}^{\circ} 1.773$, de $1^{\circ}$ de dezembro de 1980. É competência da Comissão do Patrimônio Histórico, Arqueológico, Artístico e Natural do Município (Comphaan) decidir pelo início de processos de tombamento, com base em avaliações de profissionais do órgão municipal de cultura.

3 Segundo Dário Gamboni (2014), não são equiparáveis as palavras "iconoclastia" e "vandalismo", utilizadas para rotular atos de destruição. Enquanto a palavra iconoclastia, de origem grega, significa "quebrar imagens", remetendo à querela bizantina, vandalismo é palavra associada à Revolução Francesa, neologismo cunhado no século XVIII pelo abade Henri Grégoire, para denunciar a destruição de monumentos. Atualmente, iconoclastia denota não apenas a destruição de imagens religiosas e a oposição ao uso religioso de imagens, mas também a destruição de qualquer tipo de imagem e as oposições que ensejam. Metaforicamente, significa ataques a instituições e crenças simbolizadas por imagens. Já vandalismo não se limita ao significado de destruição de obras de arte e monumentos, podendo indicar atos destrutivos diversos, desde que acusados de atos brutos e ignorantes.

4 Pixação diz respeito ao tipo de pichação praticada inicialmente em São Paulo, onde o neografismo foi adotado. De acordo com Daniel Mittmann, "podemos entender a pichação de forma genérica como toda e qualquer grafia aplicada de maneira não autorizada nos mais variados espaços públicos. Mas, dentro deste amplo espectro de pichações [...], encontramos uma espécie particular de pichação, a qual, para diferenciar-se das demais maneiras de escrita não autorizada, os próprios 'pixadores' adotaram a grafia de 'pixação'" (MITTMANN, 2013, p. 51).

\section{Referências}

BECKER, Howard S. Outsiders: estudos de sociologia do desvio. Rio de Janeiro: Zahar, 2008.

CÂMARA DOS DEPUTADOS. Projeto de Lei $n^{o}$ 706/2007. Brasília, 2007. Disponível em: <http://www.camara.gov.br/proposicoesWeb/fichadetramitacao?idProposicao $=347866>$. Acesso em: 27 ago. 2018.

CÂMARA DOS VEREADORES DE JOINVILLE. Projeto de Lei Complementar no 24/2014. Joinville, 2014a. Disponível em: <http:/ / legiscam. cvj.sc.gov.br/fusion/portal/render/Form/ view/normal?showContainer=true\&noPadding $=$ true \&autoedit $=$ true $\&$ type $=$ NeoDocument\&id=1241315\&initialContent=viewer\&user=guest $>$. Acesso em: 27 ago. 2018.

Projeto de Lei Complementar $n^{0}$ 54/2017. Joinville, 2017a. Disponível em: <http://legiscam.cvj.sc.gov.br/fusion/portal/render/ Form/view/normal?showContainer=true\&noPadding $=$ true $\&$ autoedit $=$ true $\&$ type $=\mathrm{Neo}-$ Document\&id=11632899\&initialContent=viewer\&user=guest $>$. Acesso em: 27 ago. 2018.

Projeto de Lei Ordinária $n^{\circ}$ 141/2017. Joinville, 2017b. Disponível em: http://legiscam.cvj.sc.gov.br/fusion/portal/render/ Form/view/normal?showContainer=true\&noPadding $=$ true\&autoedit $=$ true $\&$ type $=\mathrm{Neo}-$ Document\&id=11070832\&initialContent=viewer\&user=guest. Acesso em: 27 ago. 2018.

Projeto de Lei Ordinária $n^{0}$ 356/2017. Joinville, 2017c. Disponível em: <http://legiscam.cvj.sc.gov.br/fusion/portal/render/ Form/view/normal?showContainer=true\&noPadding $=$ true $\&$ autoedit $=$ true $\&$ type $=\mathrm{Neo}-$ 
Document\&id $=13910247 \&$ initialContent $=$ viewer\&user=guest $>$. Acesso em: 27 ago. 2018.

Projeto de Lei Ordinária $n^{0}$ 381/2014. Joinville, 2014b. Disponível em: <http://legiscam.cvj.sc.gov.br/fusion/portal/render/ Form/view/normal?showContainer=true\&noPadding $=$ true $\&$ autoedit $=$ true $\&$ type $=\mathrm{Neo}-$ Document\&id $=2147069 \&$ \&initialContent $=$ viewer\&user=guest>. Acesso em: 27 ago. 2018.

FOUCAULT, Michel. Isto não é um cachimbo. São Paulo: Paz e Terra, 2016.

FUNDAÇÃO CULTURAL DE JOINVILLE. Processo de Tombamento Municipal FCJ. CPC.2010-010: Rua Santos, $n^{\circ}$ 63. Joinville, FCJ, 2010.

GAMBONI, Dario. La destrucción del arte: iconoclasia y vandalismo desde la Revolución Francesa. Madrid: Cátedra, 2014.

GITAHY, Celso. O que é graffiti. São Paulo: Brasiliense, 1999.

GOFFMAN, Erving. Estigma: notas sobre a manipulação da identidade deteriorada. Rio de Janeiro: LTC, 2012.

GUERREIRO, Juliane. Projetos na Câmara de Vereadores pretendem criar ações de denúncia e combate à pichação em Joinville. Paralelo Jornalismo, Joinville, 19 maio 2017. Disponível em: $<$ http:// paralelojornalismo.com.br/index. php/2017/05/19/ projetos-na-camara-de-vereadores-pretendem-criar-acoes-de-denuncia-e-combate-a-pichacao-em-joinville/>. Acesso em: 27 ago. 2018.

HALL, Stuart. Cultura e Representação. Rio de Janeiro: PUC-Rio: Apicuri, 2016.

MITTMANN, Daniel. O sujeito-pixador: tensões acerca da prática da pichação paulista. Rio de Janeiro: Multifoco, 2013.

PEIXOTO, Paulo. A identidade como recurso metonímico dos processos de patrimonialização. Revista Crítica de Ciências Sociais, Coimbra, n. 70, p. 183-204, dez. 2004.
PREFEITURA DE JOINVILLE. Nota sobre pichação do monumento "A Barca". Página da Prefeitura de Joinville no Facebook. Joinville, 29 jun. 2014. Disponível em: <https:// www.facebook.com/prefeituradejoinville/ posts/626193040813095>. Acesso em: 27 ago. 2018.

RODRIGUES, Bruno Ramos. O encontro das ruas pelos muros da cidade de Joinville (2006-2013). Florianópolis, 2016. Dissertação (Mestrado em História) - Programa de Pós-Graduação em História, Universidade do Estado de Santa Catarina, 2016.

SENADO FEDERAL. Projeto de Lei da Câmara no 138/2008. Brasília, 2007. Disponível em: $<$ https://www25.senado.leg.br/web/atividade/materias/-/materia/87260>. Aceso em: 27 ago. 2018.

SHAPIRO, Roberta. Que é artificação? Sociedade e Estado, Brasília, v. 22, n. 1, p. 135-151, jan./ abr. 2007.

TIRE seus rosários de nossos ovários. Sujeitos: outros olhares sobre a vida. Joinville, 28 ago. 2013. Disponível em: <https://sujeitos. wordpress.com/2013/08/28/tire-seus-rosarios-dos-nossos-ovarios/>. Acesso em: 27 ago. 2018. 